\title{
Relevansi Hak Kebebasan Mengeluarkan Pendapat Dalam Pasal 28e Ayat 3 Undang Undang Dasar 1945 Negara Republik Indonesia Terhadap Kajian Fiqih Siyasah
}

\author{
Asep Mahbub Junaedi ${ }^{1}$, Siti Ngainnur Rohmah ${ }^{2}$ \\ Institut Agama Islam Al-Zaytun Indonesia (IAI AL-AZIS) \\ do \\ https://doi.org/10.32507/mizan.v4i2.816
}

\begin{abstract}
Freedom of expression is the right of every citizen to express his thoughts through written, oral, etc. freely and responsibly in accordance with the prevailing laws and regulations. In general freedom of expression is regulated in Article 28 E Paragraph 3 of the 1945 Constitution which reads everyone has the right to freedom of association, assembly and expression. Likewise, apart from the 1945 Constitution of the Republic of Indonesia, freedom of expression is also a right that is studied in depth in Islamic law, especially in the figh siyasah both in theory and practice. This study used a qualitative method with a literature approach. The data in this research were obtained from laws and regulations relating to the right to freedom of expression, namely 1945 Constitution of the Republic of Indonesia, number 9 of 1998 about Freedom of Expression in Public, and number 39 of 1999 about Law on Human Rights. The result of this research is the right to freedom of expression in its implementation based on the principles of equality and universality principles. The aim of both is to create a state order that upholds the values of human rights, because humans aspire to freedom of expressions in their life. This shows the relevance in the concept of expressing the right to freedom between both of them.
\end{abstract}

Keywords: Freedom, Human Rights, Figh Siyasah

\begin{abstract}
Abstrak
Kemerdekaan mengemukakan pendapat adalah hak setiap warga negara untuk menyampaikan pikirannya melalui tulisan, lisan, dan lain-lain secara bebas dan bertanggung jawab sesuai dengan peraturan perundang-undangan yang sedang berlaku. Secara umum kebebasan mengeluarkan pendapat diatur dalam Pasal 28 E Ayat 3 Undang-Undang Dasar 1945 bahwa setiap orang berhak atas kebebasan berserikat, berkumpul, dan mengeluarkan pendapat. Begitu pula selain dalam UUD 1945 NRI, kebebasan mengeluarkan pendapat pun merupakan suatu hak yang dikaji secara mendalam dalam hukum Islam khususnya dalam fiqih siyasah baik secara teori maupun praktek. Penelitian ini menggunakan metode kualitatif dengan pendekatan literatur. Data dalam penelitian ini diperoleh dari peraturan perundangundangan yang berkaitan dengan hak kebebasan mengeluarkan pendapat, yaitu Undangundang Dasar 1945 NRI, Undang-Undang Nomor 9 Tahun 1998 tentang Kemerdekaan Menyatakan Pendapat di Muka Umum, Undang-undang Nomor 39 Tahun 1999 Tentang Hak Asasi Manusia. Hasil penelitian ini adalah hak kebebasan mengeluarkan pendapat dalam pelaksanaannya berdasarkan kepada prinsip-prinsip persamaan dan prinsip universalitas. Tujuan keduanya adalah untuk menciptakan tatanan bernegara yang menjunjung tinggi nilai-nilai hak asasi manusia (HAM), karena manusia menurut kodratnya mencita-citakan kebebasan berpendapat dalam kehidupannya. Hal ini menunjukkan bahwa terdapat relevansi dalam konsep pengaturan hak kebebasan mengeluarkan pendapat antara keduanya.
\end{abstract}

Kata Kunci: Kebebasan, Hak Asasi Manusia, Fiqih Siyasah

\footnotetext{
* Naskah diterima tanggal: 13 September 2020, direvisi: 13 Oktober 2020, disetujui untuk terbit: 10 Desember 2020.

${ }^{1}$ Asep Mahbub Junaedi adalah mahasiswa Hukum Tata Negara Fakultas Syariah Institut Agama Islam Az-Zaytun Indonesia (IAI AL-AZIS), alamat email: amjunaedi58@gmail.com.

2 Siti Ngainnur Rohmah adalah Dosen Pada Prodi Hukum Tatanegara (Siyasah), Fakultas Syariah Institut Agama Islam Al Zaytun Indonesia, alamat email: siti.ngainnur@iai-alzaytun.ac.id.
} 


\section{A. PENDAHULUAN}

Kebebasan mengemukakan pendapat adalah hak setiap warga negara untuk menyampaikan pikirannya melalu tulisan, lisan, dan lain-lain secara bebas dan bertanggung jawab sesuai dengan peraturan perundang undangan yang sedang berlaku. Pengertian kemerdekaan mengemukakan pendapat tersebut dinyatakan dalam Pasal 1 ayat (1) Undang-Undang Nomor 9 Tahun 1998. Di sisi lain, Indonesia sebagai negara yang memakai sistem demokrasi yang kedaulatannya ditentukan oleh rakyat, sehingga suara rakyat menjadi penentu dalam tatanan bermasyarakat, berbangsa, dan bernegara. Maka, setiap warga negara diberikan kemerdekaan untuk menyampaikan pendapat di muka umum. Hak menyampaikan pendapat di muka umum dilaksanakan secara bertanggung jawab sesuai dengan peraturan perundang-undangan dalam negara yang menyelenggarakan keadilan sosial dan menjamin Hak Asasi Manusia (HAM) dengan suasana aman, tertib, dan damai.

Mengemukakan pendapat dimuka umum merupakan salah satu hak asasi manusia, yang dilindungi dan dijamin oleh konstitusi yang melekat pada setiap warga negara. Secara umum, rumusan tersebut terdapat dalam Bab XA Pasal 28A sampai Pasal 28J UUD 1945 NRI tentang Hak Asasi Manusia. Hal tersebut dipertegas dengan regulasi mengenai kebebasan mengeluarkan pendapat yang terdapat pada UU No.9 Tahun 1998 dan UU No. 39 Tahun 1999. Makna penting yang harus digali dari maksud dan tujuan kebebasan berpikir dan mengemukakan pendapat adalah adanya kebebasan masingmasing individu untuk berfikir secara mandiri tentang segala sesuatu yang ada di sekelilingnya, fenomena yang terlintas dalam pikirannya dan berpegang pada hasil pemikirannya, serta mengemukakannya dengan berbagai bentuk cara. ${ }^{3}$

Seiring dengan menguatnya kesadaran global tentang arti penting HAM pada dewasa ini, selain persoalan tentang muatan HAM yang terdapat dalam UUD 1945 yang sudah mengalami perubahan, persoalan tentang universalitas HAM dan hubungannnya dengan berbagai sistem nilai atau tradisi agama terus menjadi pusat perhatian dalam perbincangan wacana HAM kontemporer. Harus diakui bahwa agama berperan memberikan landasan etik kehidupan manusia. Perkembangan wacana global tentang HAM memberikan penilaian tersendiri bagi posisi Islam. Hubungan antara Islam dan HAM muncul menjadi isu penting mengingat di dalamnya terdapat interpretasi yang beragam yang terkesan mengundang perdebatan yang sengit, perkembangan politik global memberikan implikasi tersendiri antara hubungan Islam dan Barat. ${ }^{4}$

Berbicara tatanan Islam, secara jelas bahwa yang akan menjadi landasan sebagai tolak ukur bagaimana Islam memberikan pandangan mengenai HAM adalah sumber hukum Islam yaitu Al-Qur'an dan As-Sunnah. Lebih khusus lagi, mengenai HAM dalam tatanan ketatanegaraan Islam banyak dikaji dalam fiqih siyasah. Fiqih siyasah merupakan suatu kajian fiqih dalam bidang tatanegara yang didalamnya berisikan

${ }^{3}$ Ali Abdul Wahid Wafi, Kebebasan Dalam Islam (Al-Huriyyah Fi al-Islam). Terj. H. S. Agil Husin Al-Munawar dan Lukman Hakim Zainudin, (Jakarta: Dina Utama, 2009 M.)

${ }^{4}$ Majda El Muhtaj, Hak Asasi manusia Dalam Konstitusi Indonesia (dari UUD 1945 sampai dengan perubahan UUD 1945 Tahun 2002), (Jakarta: Kencana, 2007 M.),51. 
suatu tatanan kenegaraan berdasarkan syariat Islam, salah satu bentuknya adalah tentang Islam mengatur hak dan kewajiban bagi warga negara dalam pergaulannya dalam masyarakat.

Pengaturan mengenai hak warga negara secara spesifik diatur dalam siyasah dusturiyah dan yang menjadi landasan hukumnya adalah pendapat atau ijtihad dari para fuqaha (ahli fiqih) yang berkompeten dibidangnya. Salah satu fuqaha yang terkenal $A b u$ A'la al-Maududi menyampaikan bahwa hak-hak rakyat diataranya adalah hak atas perlindungan terhadap hidupnya, harta dan kehormatannya, hak perlindungan terhadap kebebasan pribadi, hak kebebasan menyatakan pendapat dan berkeyakinan, dan hak jaminan kebutuhan pokok hidupnya, dengan tidak membedakan kelas dan kepercayaan. Pendapat lain dikemukakan oleh seorang ulama besar yaitu Abdul Kadir Audah, beliau menyebutkan ada dua hak bagi warga negara, yaitu hak persamaan dan hak kebebasan berpikir, berakidah, berbicara, berpendidikan, dan memiliki. ${ }^{5}$

Berdasarkan paparan di atas, penulis tertarik untuk menganalisa tentang hakikat pengaturan dari Undang-Undang Negara Republik Indonesia (hukum positif) dan fiqih siyasah mengenai hak kebebasan mengeluarkan pendapat, serta implementasinya.

\section{B. METODE PENELITIAN}

Studi hukum ini menggunakan pendekatan hukum normatif. Pendekatan hukum dilakukan dengan meninjau Undang-undang Dasar 1945 NRI Pasal 28E Ayat 3 tentang Kebebasan Mengeluarkan Pendapat, Undang-Undang Nomor 9 Tahun 1998 tentang Kemerdekaan Menyatakan Pendapat di Muka Umum, Undang-undang Nomor 39 Tahun 1999 Tentang Hak Asasi Manusia. Penelitian ini menggunakan metode kualitatif dengan pendekatan literatur.

Data dalam penelitian ini diperoleh dari sumber data primer, yaitu bahan-bahan hukum yang terdiri dari peraturan perundang-undangan yang berkaitan dengan hak kebebasan mengeluarkan pendapat, yaitu Undang-undang Dasar 1945 NRI, UndangUndang Nomor 9 Tahun 1998 tentang Kemerdekaan Menyatakan Pendapat di Muka Umum, Undang-undang Nomor 39 Tahun 1999 Tentang Hak Asasi Manusia serta dari bahan hukum sekunder yaitu buku-buku, tulisan-tulisan ilmiah, jurnal hukum yang terkait dengan kebebasan mengeluarkan pendapat dalam fiqih siyasah dan hukum positif. ${ }^{6}$

\section{ANALISIS DAN PEMBAHASAN}

\section{Tinjauan Umum Tentang Hak Asasi Manusia}

Menurut Perserikatan Bangsa-Bangsa (PBB), Hak Asasi Manusia (HAM) adalah hak-hak yang melekat pada setiap manusia, yang tanpanya manusia mustahil dapat hidup sebagai manusia. Misalnya hak hidup, merupakan suatu hak yang diberikan

\footnotetext{
5 Ahmad Djajuli, Fiqih Siyasah (Implementasi Kemaslahatan Umat Dalam Rambu-Rambu Syariah, (Jakarta: Kencana, 2009 M.), 64.

${ }^{6}$ Mestika Zed, Metode Penelitian Kepustakaan, (Jakarta: Yayasan Pustaka Obor, 2014 M.), 24.
} 
sehingga setiap manusia berhak untuk melangsungkan kehidupannya. ${ }^{7}$ Dalam konstitusi Indonesia, secara hukum, menurut pasal 1 butir 1 Undang-Undang Nomor 39 Tahun 1999 tentang HAM, dirumuskan bahwa Hak Asasi Manusia adalah; "Seperangkat hak yang melekat pada hakikat dan keberadaan manusia sebagai Mahluk Tuhan Yang Maha Esa dan merupakan anugerah-Nya yang wajib dihormati, dijunjung tinggi, dan dilindungi oleh negara, hukum, pemerintah, dan setiap orang demi kehormatan serta perlindungan harkat dan martabat manusia."

Sebagai hak dasar, HAM secara kodrati melekat secara mutlak pada diri manusia sebagai mahluk tuhan, konsekuensinya setiap individu memiliki kesetaraan (equality). Hak-hak dasar ini saling berhubungan tidak bisa dipisahkan dan tidak bisa dibagi-bagi. Memang sejatinya HAM harus memiliki sifat-sifat demikian yang terkandung di dalamnya prinsip-prinsip dasar yang bersifat asasi. Berdasarkan subtansi dari paparan diatas, secara umum HAM memiliki prinsip-prinsip dasar yang sejatinya terkandung dalam HAM itu sendiri. Oleh karena itu, hak-hak dasar yang termuat dalam HAM dijadikan dan menjadi beberapa prinsip.

Prinsip dalam HAM ada empat, yaitu universal (universality), tak terbagi (indivisibility), saling bergantung (interdependent), dan saling terkait (interrelated). Kemudian ditambahkan oleh Rhona K. M. Smith dengan prinsip lainnya, yaitu kesetaraan (equality), non-diskriminasi (non-discrimination), dan kewajiban positif setiap negara untuk melindungi hak-hak tertentu. ${ }^{8}$ Prinsip-prinsip ini telah menjadi landasan dalam hukum HAM. Dari prinsip tersebut memiliki makna yang besar bagi kehidupan individu manusia sebagai pemilik hak yang melekat semenjak ia dilahirkan.

\section{Telaah Pelaksanaan Hak Asasi Manusia di Indonesia}

Dalam perjalanannya HAM lahir dan berkembang melalui masa yang sangat panjang. Konsep HAM bagi Indonesia dirumuskan dalam Undang-Undang Dasar 1945. Perumusan UUD 1945 belum terpengaruh oleh UDHR karena lahir lebih awal sehingga kandungan HAM yang tertuang di dalamnya merupakan pikiran-pikiran yang didasarkan tradisi budaya masyarakat itu sendiri. ${ }^{9}$ Mengenai jaminan UUD 1945 terhadap HAM terdapat tiga pandangan yang hampir senada; pertama adalah kelompok yang berpendapat bahwa UUD 1945 tidak memberikan jaminan hukum terhadap HAM secara komprehensif, pendapat yang kedua yaitu bahwa UUD 1945 telah memberikan jaminan secara komprehensif terhadap HAM, dan yang ketiga berpendapat bahwa hanya memberikan jaminan pokok terhadap HAM yang terkandung dalam UUD 1945.10 Undang-Undang Dasar 1945 merupakan sistem konstitusi, termasuk didalamnya pembukaan UUD 1945. Bila dikaitkan dengan Hak

7 Tim ICCE UIN, Demokrsasi, Hak Asasi Manusia dan Masyarakat Madani, (Jakarta: Prenada Media. Cet. 2. 2005 M.), 110.

8Majaid Kumkelo et al, Fiqih HAM, (Malang: Stara Press, 2015 M.), 35.

${ }_{9}^{9}$ Widiada Gunakaya, Hukum Hak Asasi Manusia, 25.

10 Arman Suadi, Filsafat Hukum (Refleksi Filsafat Pancasila, Hak Asasi Manusia, Dan Etika), (Jakarta: Kencana, 2019 M.), 168. 
Asasi Manusia (HAM) didalam pembukaan UUD 1945 terdapat nilai-nilai HAM yang berfungsi sebagai grundnorm bagi perundang-undangan yang berada di bawahnya. Akan tetapi di dalam batang tubuh tidak terdapat bab yang mengatur HAM secara jelas terhadap perlindungan HAM, pengaturannya tersebar dalam beberapa pasal. Ada 7 pasal yang langsung mengatur tentang jaminan perlindungan terhadap HAM, yaitu Pasal 27, 28, 30, 31, 33, dan 34.

Dalam UUD 1945 secara subtansi sudah memiliki keterkaitan dengan nilai-nilai HAM diantaranya pada alinea pertama dalam pembukaan terkandung subtansi hakikat adanya kebebasan untuk merdeka, martabat manusia dan keadilan. Alinea kedua, terkandung subtansi nilai HAM bahwa Indonesia selain menjunjung tinggi keadilan, juga mengakui HAM dibidang politik, sosial dan budaya. Selanjutnya pada alinea ketiga, terkandung subtansi nilai HAM. Rakyat Indonesia menyatakan kemerdekaannya sehingga menjelma menjadi bangsa yang bebas sesuai dengan nilai HAM adanya persamaan dalam politik, sosial, dan budaya. Alinea terakhir mengandung subtansi nilai HAM yakni pengakuan dan perlindungan dalam segala bidang kehidupan, sepeti ekonomi, politik, sosial budaya, pertahanan dan keamanan.

Setelah dilakukan perubahan atau amandemen terhadap UUD 1945, terutama pada perubahan kedua, muatan HAM mendapatkan perhatian yang lebih besar, terdapat bab tersendiri yaitu Bab XA, terdiri dari Pasal 28A sampai Pasal 28J dengan masing-masing pasal terdiri dari beberapa butir peraturan terhadap HAM. Dengan adanya amandemen ini diharapkan sebagai negara yang memakai sistem demokrasi menyatakan bahwa dimensi konstitusi telah menetapkan dan mengatur secara jelas terhadap prinsip-prinsip Hak Asasi Manusia.

\section{Jaminan Kebebasan Mengeluarkan Pendapat Menurut Undang-Undang Dasar NRI} Tahun 1945

Sebagai negara hukum, negara Indonesia menjalankan seluruh aspek pemerintahannya mengikuti regulasi yang tertulis sedemikian rupa dalam undangundang. Begitu pula mengenai hak kebebasan mengeluarkan pendapat telah ditetapkan undang-undang yang mengaturnya. Tujuan undang-undang yang mengatur mengenai kebebasan menyatakan pendapat dan berserikat itu adalah suatu ketetapan yang menerangkan terhadap kebebasan berpendapat baik secara lisan maupun tertulis. Dalam rangka kebebasan menyampaikan pendapat tersebut, maka setiap orang berhak mengumpulkan bahan-bahan yang dibutuhkannya, sehingga harus dijamin haknya untuk mencari, memperoleh, memiliki, menyimpan, mengolah, dan menyampaikannya. Dibalik itu, ada ketentuan undang-undang yang melarang siapapun, termasuk pemerintah yang ingin mengurangi, membatasi atau meniadakan kebebasan tersebut. ${ }^{11}$

\footnotetext{
${ }^{11}$ Krisna Harahap, HAM dan Upaya Penegakkannya di Indonesia, (Bandung: Grafiti, 2003 M.)
} 
Dasar hukum sebagai jaminan atas kebebasan berpendapat di Indonesia, telah tertuang dalam peraturan perundang-undangan yang tertera di bawah ini:

a. Undang-Undang Dasar Negara Republik Indonesia 1945.

i) Pasal 28 menyatakan bahwa "kemerdekaan berserikat dan berkumpul, mengeluarkan pikiran dengan lisan dan tulisan dan sebagainya ditetapkan dengan undang-undang."

ii) Pasal 28 E ayat (2) menyatakan bahwa "setiap orang berhak atas kebebasan meyakini kepercayaan, menyatakan pikiran dan sikap, sesuai dengan hati nuraninya."

iii) Pasal 28 E ayat (3) menyatakan bahwa "setiap orang berhak atas kebebasan berserikat, berkumpul, dan mengeluarkan pendapat."

iv) Pasal 28 F menyatakan bahwa "setiap orang berhak berkomunikasi dan memperoleh informasi untuk mengembangkan pribadi dan lingkungan sosialnya, serta

v) berhak untuk mencari, memperoleh, memiliki, menyimpan, mengolah, dan menyampaikan informasi dengan menggunakan segala jenis saluran yang tersedia."

b. Undang-Undang Nomor 9 Tahun 1998 tentang Kemerdekaan Menyampaikan Pendapat di Muka Umum. Ketentuan Pasal 2 yang menyatakan bahwa "setiap warga negara, secara perorangan atau kelompok, bebas menyampaikan pendapat sebagai perwujudan hak dan tanggung jawab berdemokrasi dalam kehidupan bermasyarakat, berbangsa, dan bernegara."

c. Undang-Undang Nomor 39 Tahun 1999, tentang Hak Asasi Manusia. Dalam Pasal 23 ayat (2) menyebutkan bahwa "setiap orang bebas untuk mempunyai, mengeluarkan dan menyebarluaskan pendapat sesuai hati nuraninya, secara lisan dan atau tulisan melalui media cetak maupun elektronik dengan memperhatikan nilai-nilai agama, kesusilaan, ketertiban, kepentingan umum, dan keutuhan Negara."

d. Undang-Undang No. 12 Tahun 2005 tentang Pengesahan Internasional Covenant on Civil and Political Rights (Kovenan Internasional Tentang Hak-Hak Sipil Dan Politik). Dalam Undang-Undang ini tidak diatur lebih lanjut mengenai hak-hak sipil dan politik yang ada di Indonesia, sebab Undang-Undang ini meratifikasi secara keseluruhan dari Kovenan Internasional tentang Hak Sipil dan Politik. Jadi apapun yang menjadi substansi dalam Kovenan Internasional Hak Sipil dan Politik juga merupakan isi dari Undang-Undang No.12 Tahun 2005 dan merupakan bagian yang tak terpisahkan, seperti yang tertulis dalam Undang-Undang tersebut.

Berdasarkan peraturan yang telah tertulis diatas, secara hukum hak atas kebebasan mengeluarkan pendapat merupakan hak yang dilindungi keberadaannya. Kebebasan merupakan Hak Asasi Manusia sebagai anugerah dari Tuhan yang perlu dijaga, dihormati dan dijunjung tinggi oleh seluruh umat manusia dalam hidup bermasyarakat, berbangsa, dan bernegara. 


\section{Hak Asasi Manusia dalam kajian Fiqih Siyasah}

Definisi fiqih siyasah adalah ilmu tatanegara Islam yang secara spesifik membahas tentang seluk-beluk pengaturan kepentingan umat manusia pada umumnya dan negara pada khususnya, berupa penetapan hukum, pengaturan dan kebijakan oleh pemegang kekuasaan yang bernafaskan atau sejalan dengan ajaran Islam, guna mewujudkan kemaslahatan bagi manusia dan menghindarkannya dari berbagai kemudaratan yang mungkin timbul dalam kehidupan masyarakat, berbangsa, dan bernegara yang dijalaninya. ${ }^{12}$

Secara garis besar, objek kajian fiqih siyasah meliputi aspek pengaturan hubungan antara warga negara, hubungan antara warga negara dengan lembaga negara, dan hubungan antara lembaga negara dengan lembaga negara, baik hubungannya bersifat intern suatu negara maupun ekstern. Dari pemahaman tersebut, tanpak bahwa kajian siyasah terfokus pada bidang pengaturan. Pengaturan yang pertama adalah pengaturan terhadap undang-undang, kedua, pengorganisasian dan pengaturan kemaslahatan, ketiga, hubungan antara penguasa dan rakyat serta hak dan kewajiban masing-masing dalam mencapai tujuan negara.

Sumber hukum fiqih siyasah atau politik Islam bersumber dari Al-Quran dan AsSunnah serta pemikiran dan praktek kenegaraan yang terjadi pada masa Nabi Muhammad SAW. memimpin, khulafaurrasidin, Bani Umayah dan Bani Abbasiah dan dinasti Islam lainnya. Al-Quran menegaskan bahwa Islam agama rahmatan lil 'aalamiin dan merupakan ajaran yang sempuna. Disamping mengajarkan kepada manusia bagaimana menjalin hubungan dengan pencipta, Islam pun memberi pengajaran bagaimana kita bergaul dengan sesama. Ajaran pokok hablu minallaah dan hablu minannaas menghadirkan dua konsep hak, yakni hak manusia dan hak Allah. Setiap hak saling melandasi hak yang lainnya, hak Allah melandasi hak manusia dan begitu juga sebaliknya. Mengenai kehidupan manusia didasarkan atas landasan teosentrik, dimana Allah yang menentukan ketentuan syariatnya sebagai tolak ukur baik dan buruknya tatanan kehidupan manusia secara pribadi maupun sebagai warga negara. ${ }^{13}$

HAM dalam ajaran Islam terdiri dari tiga tingkatan, yaitu, a) Pertama, hak dasar (hak dharury) yaitu hak yang melekat sejak ia lahir sebagai manusia, yang apabila hak ini dilanggar maka bukan hanya membuat manusia sengsara, tetapi juga hilang eksistensinya, misalnya hak hidup, b) Kedua, hak sekunder (hak hajy) yaitu hak untuk memenuhi kebutuhan untuk hidup, apabila hak ini tidak terpenuhi maka akan hilang hak hidupnya, misalnya hak untuk mendapatkan sandang pangan yang layak, c) Ketiga, hak tersier (hak tahsiny) yaitu hak pelengkap dalam memenuhi kemajuan dan pengembangan diri, hak ini tingkatannya lebih rendah dari hak dasar dan hak sekunder.

Fiqih siyasah merupakan suatu landasan konstitusional bagi pemerintahan yang berdasarkan hukum Islam, bagaimana negara menjalankan roda pemerintahan demi kemaslahatan warga negaranya. Tujuan yang ingin dicapai dalam suatu negara

${ }^{12}$ Mujar Ibnu Syarif. \& Hamami Zada, Fiqih Siyasah (Doktrin dan Pemikiran Politik Islam), (Jakarta: Erlangga, 2008 M.), 11.

${ }^{13}$ Said Aqiel Siradj, Hak Atas Keadilan Dalam Wacana Islam, (Jakarta: ELSAM, 1998 M.), 142. 
tentunya tidak akan berhasil bila tidak ada prinsip yang menjadi pegangan dalam meraih tujuan tersebut. Prinsip sangat diperlukan sebagai pegangan dalam mengatur warga negara sehingga tujuan dari hukum tersebut dapat tercapai. Dalam figih siyasah, syariat atau hukum memiliki beberapa tujuan seperti yang telah dirumuskan oleh Abu Ishak Asy-Syatibi, yang disebut dengan Maqosidu Asy-Syari'ah, antara lain hifdzu ad-din (perlindungan terhadap agama/keyakinan), hifdzu an-nafs (perlindungan atas hak hidup), hifdzu al-aql (perlindungan atas akal), hifdzu al-mal (perlindungan atas harta benda), dan hifdzu an-nasb (perlindungan terhadap keturunan). ${ }^{14}$

Sedangkan secara normatif pelaksanaan HAM di dalam fiqih siyasah berdasarkan hukum Islam didasari oleh beberapa prinsip. ${ }^{15}$ Diantara prinsip tersebut yaitu:

a) Prinsip persamaan antar manusia, yaitu semua manusia mempunyai kedudukan yang sama dihadapan Tuhan, tidak ada satu ras yang lebih unggul dari yang lain, karena manusia mempunyai leluhur yang sama.

b) Prinsip kebebasan personal, oleh karena itu Islam melarang perbudakan dan mewajibkan untuk memberikan kemerdekaan pada budak. Landasan hukumnya adalah Al-Quran surat Al-Baqarah (2) ayat 177.

c) Prinsip keselamatan jiwa, menyelamatkan jiwa berarti menyelamatkan manusia seutuhnya. Sebagaimana ungkapan yang disampaikan oleh khalifah Ali bin Abu Thalib bahwa darah non muslim (dzimmi) suci sebagaimana darah orang muslim dan harta mereka pun harus dilindungi. Landasan hukum dari prinsip yang ketiga adalah Al-Quran surat Al-Maidah (5) ayat 32.

d) Prinsip keadilan, keadilan merupakan hak yang sangat ditekankan di dalam AlQuran. Dasar hukum dari prinsip keadilan adalah Al-Quran surat Al-A'raf (7) ayat 29 dan Al-Hadid (57) ayat 25.

Di dalam ketatanegaraan Islam prinsip amar ma'ruf nahi munkar merupakan asas dasar pijakan kebebasan. Doktrin ketatanegaraan Islam memberikan kebebasan berpendapat akan tetapi harus memiliki alasan yang jelas. Bahkan bagi umat Islam sendiri diwajibkan berkata benar walau berat untuk dilakukan. Ada beberapa cakupan dalam kebebasan berpendapat yaitu, kebebasan memberikan nasehat, kebebasan melakukan pengawasan dan kebebasan memberikan keritikan.

Konsep Islam tentang kebebasan mengeluarkan pendapat jauh lebih tinggi dari pada yang diakui Barat. Memang, hak untuk kebebasan mengeluarkan pendapat guna menyebarkan kebaikan dan kebajikan bukan hanya semata-mata hak, tetapi satu kewajiban. Siapapun yang berusaha menyangkal hak ini terhadap rakyatnya secara terang-terangan menentang Tuhan yang Maha Kuasa. ${ }^{16}$

Hak kebebasan mengeluarkan pendapat kedudukannya sama dengan hak dan kewajiban terhadap individu untuk berusaha menghentikan kejahatan, baik kejahatan ini dilakukan oleh individu atau kelompok orang atau pemerintah salah satu negara

${ }^{14}$ Ahmad Sudirman Abbas, Fiqih Siyasah, 8.

${ }^{15}$ Mujaid Kumkelo et al. Fiqih HAM, 48.

${ }^{16}$ Mujaid Kumkelo et al. Fiqih HAM, 71. 
atau pemerintah negara lain. Al-Qur'an telah menjelaskan tentang perintah untuk menyuarakan kebenaran dalam QS. Ali Imran (3) ayat 110, 'Mereka menganjurkan perbuatan yang baik dan melarang perbuatan yang mungkar".

Tujuan utama suatu pemerintah Islam telah ditentukan oleh Allah dalam AlQur'an sebagai berikut: "Jika Kami beri kekuasaan kepada orang-orang ini di bumi mereka mengerjakan shalat dan menunaikan zakat, menyuruh berbuat kebaikan, melarang berbuat kemungkaran' (QS. Al- Hajj (22) ayat 41). Kemudian dalam sebuah hadits Rasulullah SAW. juga menegaskan bahwa apabila ada seseorang menyaksikan perbuatan tercela, maka ia harus berusaha menghentikannya, paling tidak dengan lidahnya atau mengutuknya dalam hati. Inilah tingkat keimanan paling lemah. Pendapat Al-Maududi ini bisa dijadikan dasar bagi kita bahwa syariat Islam secara jelas memberikan kepada umatnya atas hak kebebasan berpendapat kepada seluruh warga negara, akan tetapi kebebasan ini digunakan semata-mata untuk suatu kebaikan tidak untuk hal-hal yang dilarang oleh agama.

Mengenai hak kebebasan mengemukakan pendapat, dalam ketatanegaraan Islam, nilai-nilai HAM esensinya telah dilaksanakan dalam tatanan kehidupan oleh Nabi Muhammad SAW dan para sahabatnya ketika beliau memimpin umat Islam. Hal ini berdasarkan dengan adanya bukti-bukti bahwa Nabi Muhammad memberikan kebebasan untuk berbicara kepada para sahabat dan mengemukakan pendapat mereka. Ini tampak jelas dalam musyawarah-musyawarah dan konsultasi yang beliau laksanakan untuk membahas berbagai persoalan atau penetapan suatu kelonggaran kepada mereka untuk menentukan pilihan.

\section{Relevansi Hak Kebebasan Mengeluarkan Pendapat Dalam Pasal 28E Ayat 3 Undang Undang Dasar 1945 Negara Republik Indonesia Terhadap Kajian Fiqih Siyasah}

Dalam Kamus Besar Bahasa Indonesia, kata relevansi mengandung makna hubungan, atau kaitan antara satu hal dengan hal yang lainnya. Sebelum disimpulkan mengenai relevansi hak kebebasan mengeluarkan pendapat dalam Pasal 28E Ayat 3 UUD 1945 Negara Republik Indonesia terhadap kajian figih siyasah, terlebih dahulu penulis harus mengurai beberapa faktor yang akan mendukung terhadap sebuah pengamatan sehingga mendapatkan sebuah kesimpulan yang benar.

Faktor yang pertama, HAM dalam konteks fiqih siyasah dan secara umum dalam hukum positif memiliki arti yang hampir sama yaitu hak dasar yang melekat pada diri manusia karena kodrat kemanusiaannya, sebagai anugerah dari Tuhan Yang Maha Esa. Hal ini bisa dijadikan faktor pendukung mengenai relevansi kebebasan mengeluarkan pendapat antara dua konsep hukum tersebut.

Setelah kita telaah dari segi pengertian dan prinsip atas hak kebebasan mengeluarkan pendapat, faktor berikutnya yang bisa dijadikan indikator bahwa adanya relevansi antara kebebasan mengeluarkan pendapat dalam kedua aturan hukum ini adalah adanya kesamaan tujuan hukum. Tujuan dari kebebasan mengemukakan 
pendapat yaitu untuk mewujudkan kebebasan yang bertanggung jawab sebagai salah satu pelaksanaan hak asasi manusia sesuai dengan Pancasila dan UUD 1945, mewujudkan perlindungan hukum yang konsisten dan berkesinambungan dalam menjamin kemerdekaan menyampaikan pendapat, mewujudkan iklim yang kondusif bagi berkembangnya partisipasi dan kreativitas setiap warga negara sebagai perwujudan hak dan tanggung jawab dalam kehidupan berdemokrasi, dan untuk menempatkan tanggung jawab sosial kehidupan bermasyarakat, berbangsa, dan bernegara, tanpa mengabaikan kepentingan perorangan atau kelompok.

Sedangkan tujuan hukum dalam fiqih siyasah adalah tercapainya maslahah kehidupan manusia sebagaimana yang sudah dijelaskan diatas. Tujuan hukum tersebut dapat terpenuhi manakala manusia senantiasa berusaha untuk menjaga dan merawatnya dengan baik. Tentunya subtansi dari masing-masing tujuan hukum adalah sama, tujuan hukum yang terkandung dalam fiqih siyasah telah mengakomodir dari tujuan hukum dari kebebasan mengeluarkan pendapat yang terdapat dalam Pasal 28E Ayat 3 UUD 1945. Relevansi antara keduanya jelas nampak sebagai suatu kesatuan yang saling keterkaitan.

Secara umum tujuan kebebasan mengemukakan pendapat dalam fiqih siyasah adalah untuk menyeru manusia untuk berbuat kebaikan dan mengkritisi perbuatan atau hal yang menyimpang dari aturan hukum baik antara individu dengan individu maupun individu terhadap pemerintah. Dari kedua sistem tatanan hukum baik hukum positif maupun fiqih siyasah dalam pelaksanaan hak atas kebebasan berpendapat ini harus dimanfaatkan untuk tujuan menyebarkan kebaikan, dan tidak untuk menyebarluaskan kejahatan dan kezaliman. Seseorang boleh mengemukakan pendapat secara bebas, asalkan tidak melanggar hukum seperti penghujatan, fitnah, melawan kebenaran, menghina keyakinan orang lain atau dengan mengikuti kemauan sendiri. Dan dalam keadaan bagaimanapun aturan mana pun tidak akan mengizinkan kejahatan dan kekejian, dan juga tidak memberikan hak kepada siapa pun untuk menggunakan bahasa yang keji atau menghina atas nama kritik.

Oleh karena itu kebebasan berpendapat harus sesuai dengan prinsip dasar, yakni mewajibkan setiap manusia supaya menegakkan dan melaksanakan yang benar, menghapus dan menghindari yang salah. Secara subtansi dari kedua tujuan kebebasan mengeluarkan pendapat pada Pasal 28E ayat 3 UUD 1945 sama dengan tujuan hukum yang diatur dalam fiqih siyasah, dan merupakan suatu tatanan hukum yang menjunjung tinggi hak asasi manusia (HAM), hal ini pun bisa dijadikan sebuah indikator bahwa memang kedua aturan ini memiliki relevansi dalam makna dan tujuannya.

\section{KESIMPULAN}

Kebebasan mengeluarkan pendapat dengan jelas telah diatur dalam pasal $28 \mathrm{E}$ Ayat 3 UUD 1945 Negara Republik Indonesia, bahwa setiap orang berhak atas kebebasan berserikat, berkumpul, dan mengeluarkan pendapat. Peraturan perundangundangan turunan yang mengatur tentang hak kebebasan mengeluarkan pendapat 
adalah Undang-Undang Nomor 9 Tahun 1998 tentang Kemerdekaan Menyampaikan Pendapat di Muka Umum. Kemudian kebebasan mengeluarkan pendapat diatur pula dalam Undang-Undang Nomor 39 Tahun 1999 tentang Hak Asasi Manusia. Dalam fiqih siyasah (sistem tatanegara Islam) telah jelas mengatur dan memberikan kebebasan dan keleluasaan untuk mengeluarkan pendapat kepada seluruh warga negara, dengan syarat bahwa hak itu digunakan untuk menyebarkan kebaikan dan untuk mencegah keburukan. Hak tersebut bukan hanya semata-mata hak, tetapi juga merupakan satu kewajiban bagi seluruh warga negara.

Hak kebebasan mengeluarkan pendapat pada Pasal 28E ayat 3 UUD 1945 dan dalam kajian fiqih siyasah dalam pelaksanaannya berdasarkan kepada prinsip-prinsip yang sama. Diantara prinsip tersebut yang paling mendasar adalah prinsip equalitas (persamaan) dan prinsip universalitas (menyeluruh). Tujuan keduanya pun memiliki keselarasan yaitu semata-mata untuk menciptakan tatanan bernegara yang menjunjung tinggi nilai-nilai hak asasi manusia (HAM), karena manusia menurut kodratnya mencita-citakan kebebasan berpendapat dalam kehidupannya. Hal inilah yang menjadi dasar bahwa terdapat relevansi dalam konsep pengaturan hak kebebasan mengeluarkan pendapat antara keduanya.

\section{REFERENSI}

Abbas, Ahmad Sudirman. 2015. Fiqih Siyasah. Jakarta: Abbas Press.

Al-Zuhaili, Wahbah. 2004. al-Figh al-Islami wa Adillatuhu. Damaskus: Dar alFikr.Asshiddiqie, Jimly. 2006. Kemerdekaan Berserikat, Pembubaran Parati Politik dan Mahkamah Konstitusi. Jakarta: Konstitusi Press.

Djajuli, H.A.2009. Fiqih Siyasah (Implementasi Kemaslahatan Umat Dalam Rambu-Rambu Syariah. Jakarta: Kencana.

El Muhtaj, Majda. 2007. Hak Asasi manusia Dalam Konstitusi Indonesia (dari UUD 1945 sampai dengan perubahan UUD 1945 Tahun 2002). Jakarta: Kencana.

Gunakaya, Widiada. 2017. Hukum Hak Asasi Manusia. Jakarta: Andi.

Harahap, Krisna. 2003. HAM dan Upaya Penegakkannya di Indonesia. Bandung: Grafiti.

Iqbal, Muhammad. 2014. Fiqih Siyasah (Kontektualisasi Doktrin Politik Islam). Jakarta: Gaya Media Pratama.

Kumkelo, Majid, Anas Kholish dan Aulia Ali. 2015. Fiqih HAM. Malang: Stara Press.

Siradj, Said Aqiel. 1998. Hak Atas Keadilan Dalam Wacana Islam. Jakarta: ELSAM.

Syarif, Mujar Ibnu \& Zada, Hamami. 2008. Fiqih Siyasah (Doktrin dan Pemikiran Politik Islam). Jakarta: Erlangga.

Tim ICCE UIN. 2005. Demokrasi, Hak Asasi Manusia dan Masyarakat Madani. Jakarta: Prenada Media. Cet. 2. 
Zed, Mestika. 2014. Metode Penelitian Kepustakaan. Jakarta: Yayasan Pustaka Obor.

Muzzahidin, Muhamad Ina. 2010. Konsep Kebebasan Dalam Islam. [Skripsi]. Semarang. Fakultas Ushuluddin dan Humaniora, Universitas Negeri Islam Walisongo.

Nugroho, Aris Setyo. 2010. Perlindungan Kebebasan Berpendapat Melalui Media Internet Dalam Undang-Undang No. 11 Tahun 2008 Tentang Informasi Dan Transaksi Elektronik Ditinjau Dari Perspektif Hak Asasi Manusia. [Skripsi] Universitas Sebelas Maret. Surakarta.

Sabri Bun Mamat, Mohd. 2010. Kebebasan Berpendapat Dalam Hukum Indonesia Dan Malaysia (Analisis Hukum Positif Dan Hukum Islam. [Skripsi]. Jakarta. Fakultas Hukum UIN Syarif Hidayatullah Jakarta

Undang-Undang Dasar 1945 Negara Republik Indonesia.

Undang-Undang Nomor 9 Tahun 1998 Tentang Kebebasam Mengeluarkan Pendapat

Undang-Undang Nomor 39 Tahun 1999 Tentang Hak Asasi Manusia (HAM) 